\title{
Civil Society, Legitimacy and Political Space: Why Some Organisations are More Vulnerable to Restrictions than Others in Violent and Divided Contexts
}

\author{
Rowan Popplewell ${ }^{1}$
}

Published online: 5 February 2018

(C) The Author(s) 2018. This article is an open access publication

\begin{abstract}
This paper examines legitimacy and political space for civil society in violent and divided contexts. It draws on qualitative fieldwork with civil society groups in Burundi, where government restrictions and political violence have increased in recent years. However, not all civil society groups experienced these pressures in the same way, and some were more vulnerable to restrictions than others. This paper asks why and considers whether civil society legitimacy can help to explain some of these differences. In doing so, it develops a more nuanced understanding of the relationship between legitimacy and political space, and processes of legitimation and delegitimation in violent and divided contexts. The paper finds that the experiences of civil society groups in Burundi prior to the 2015 elections not only related to their organisational legitimacy, but also the extent to which they were perceived to challenge the political legitimacy of government elites.
\end{abstract}

Keywords Civil society · Political space - Legitimacy · Burundi

\section{Introduction}

Eighteen months after widespread protests erupted following the announcement that the President would run for an unconstitutional third term, the Burundian Government

Rowan Popplewell

rowanpopplewell@gmail.com;

rowan.popplewell@ouce.ox.ac.uk

1 School of Geography and the Environment, University of Oxford, South Parks Road, Oxford OX1 3QY, UK banned five of the country's leading human rights organisations. The statement issued by the Ministry of the Interior said that the groups, many of which were involved in organising the protests, had 'tarnished the image of the country' and 'sowed hatred and division in the heart of the population'. ${ }^{1}$ Pressure on political and operating space for civil society in Burundi was nothing new; the government had introduced a number of restrictions in the years preceding the controversial elections in 2015. However, not all organisations experienced these restrictions and pressures in the same way. Much of the existing policy literature on political and operating space for civil society argues that groups and individuals that work on human rights or democracy promotion are more vulnerable to restrictions and pressures (ACT Alliance 2011; ACT Alliance and CIDSE 2014; Civicus 2013; Trócaire 2012; Carothers and Brechenmacher 2014). This study finds that while some civil society groups who worked on human rights and democracy promotion activities in Burundi were subject to harassment and intimidation, others were able to work on these issues without experiencing constraints.

This paper asks why some Burundian civil society organisations were more vulnerable to restrictions than others, and considers whether civil society legitimacy can help to explain some of these differences. It draws on qualitative evidence from Burundi, gathered from 83 semistructured interviews with representatives from 25 domestic civil society groups, as well as international nongovernmental organisations and multilateral

\footnotetext{
${ }^{1}$ Interior Minister Pascal Barandagiye quoted by Carina Tertsakian on 26 October 2016 in 'Fearing Dissent, Burundi's Government Clamps Down: Activists banned, Media punished', Human Rights Watch Dispatches, available online at https://www.hrw.org/news/ 2016/10/26/fearing-dissent-burundis-government-clamps-down (Accessed 1 December 2016).
} 
institutions, which were conducted over 6 months between June 2014 and April 2015. The Burundian government did not respond to interview requests, despite repeated attempts to contact them. The heightened security situation at the time of research also made it difficult to gather evidence from the communities that these civil society groups worked with. Consequently, the research relies on organisational perceptions of their own legitimacy, as well as the views of those working for international NGOs and multilateral organisations in Burundi, and public statements made by the Burundian government. There is a risk that organisations and activists may overstate their own legitimacy with particular constituencies. However, interviewees were found to be open and reflective when it came to assessing their relationship with the Burundian Government and how they were perceived by the ruling elite. In most cases, the statements made by individual activists also corresponded with evidence gathered from interviewees working with international organisations in Burundi and were backed up by public statements made by the Burundian government.

The paper focuses on the experiences of thirteen domestic civil society organisations that worked on human rights and democracy promotion issues in Burundi. Organisations and individual respondents will not be named due to the heightened political situation in Burundi at the time of writing. Activists working for five of these organisations explained that either they or their colleagues had experienced harassment and intimidation or other pressures in the run up to the 2015 elections, while those working for the eight other organisations did not have direct experience of restrictions. The paper examines a number of different explanations for this including organisational function (e.g. monitoring, advocacy, socialisation), organisational behaviour (e.g. approach to engaging with authorities) and organisational values (e.g. whether an organisation is faith-based or secular). It argues that these factors are extremely important, but do not on their own explain why some organisations faced more severe pressures than others. If we look at these aspects through the lens of legitimacy, a much more interesting picture emerges. Consequently, the paper considers whether the experiences of these organisations also relate to their organisational legitimacy, and the extent to which they and the individual activists associated with them were perceived to challenge the political legitimacy and authority of government elites.

The connections between legitimacy and political space for civil society are relatively unexplored within the existing literature on political space for civil society and civil society legitimacy. This paper seeks to build a deeper and more nuanced understanding of the relationship between legitimacy and political space for civil society in contexts that are marked by violence and political division. It views both legitimacy and political space as situated processes that are negotiated and contested. Consequently, they are both often 'a matter of degree' rather than something absolute, which you either have or you do not (Walton 2013: 21). Furthermore, both concepts are also relational and concern perceptions. Whereas legitimacy relates to the perceptions of external constituencies (such as national governments, international organisations or grassroots communities), political space relates to the perceptions of civil society actors themselves. The paper begins by exploring definitions of civil society legitimacy and political space within the literature in greater depth, and looks at the existing research on legitimacy in violent and divided contexts. It will then explore the issues of political space for civil society in Burundi and discuss some of the factors that may explain why some organisations were able to work on issues considered to be political or sensitive without experiencing direct restrictions and others were not.

\section{Legitimacy and Political Space for Civil Society}

The connections between legitimacy and political space for civil society are relatively unexplored within the relevant literature. One possible explanation for this is that much of the existing research on civil society legitimacy is focused on organisations rather than the social and political landscape within which they are situated. The literature on political space, on the other hand, concentrates on external environment, namely the restrictions placed on civil society groups, rather than how organisations themselves might influence this space. Where the characteristics and behaviours of organisations are considered, possible connections to civil society legitimacy are not addressed (van der Borgh and Terwindt 2014; Dupuy et al. 2015). However, there are some authors that highlight the connections between broader struggles for political legitimacy and either organisational legitimacy (Walton 2008, 2013), or political space for civil society (Wood 2016; van der Borgh and Terwindt 2014). This paper is influenced by the work of these authors and seeks to further develop their arguments.

\section{Civil Society Legitimacy}

Generally speaking, political legitimacy relates to the acceptance of an authority as just and proper. For Weber (1964), a political authority is considered as legitimate when its subjects have faith in it and consequently are willing to obey it. Weber is interested in understanding how legitimacy is produced. Consequently, his definition of 
legitimacy is strictly descriptive, but the concept also has strong normative dimensions. Here, an authority is considered to be legitimate when it meets certain standards or embodies particular norms. However, purely normative definitions can neglect the processes through which legitimacy is constructed and reproduced, as well as the ways in which it is eroded and undermined. Within the Weberian tradition, legitimacy is associated with the state, which is considered to be the primary source of political legitimacy. However, legitimacy is also produced in structures and spaces beyond the state, such as governments-in-exile and liberation movements. Jeffrey, McConnell and Wilson examine these alternative sites of legitimacy in order to 'shine a light on the wider arena of political actors, forms of agency and sites of contestation through which legitimacy is produced' (2015: 177). By focusing on these alternative sites, they seek to 'unsettle an image of political legitimacy that has often foregrounded the sovereign state as the sole arbiter and provider of legitimacy' (Jeffrey et al. 2015: 177).

One such alternative site is civil society. Organisations and individuals within civil society have the potential to reinforce or challenge the legitimacy of the state (which can be problematic, especially in places torn by violence and political divisions where is authority contested). They may also have political legitimacy in their own right. The existing literature on civil society legitimacy is primarily focused on the legitimacy of organisations; either nongovernmental organisations (NGOs) (Atack 1998; Edwards 1999; Brown 2001; Lister 2003; Brown and Jagadananda 2007; Walton 2008, 2013) or international NGOs and transnational civil society networks (Brown 2008; Walton et al. 2016). Several definitions of organisational legitimacy exist within the literature, the most prominent of which is that of Suchman, who defines it as 'a generalised perception or assumption that the actions of an entity are desirable, proper or appropriate within some socially constructed system of norms, values, beliefs and definitions' (1995: 574). Most definitions contain a strong normative dimension. Organisations that are considered to be legitimate are those that 'are seen to be appropriate and accepted actors whose activities can be justified in terms of the values, norms, laws and expectations of their social contexts' (Brown 2008: 2) and 'enjoy the support of an identifiable community' (Edwards 1999: 258). For these writers, an organisation's legitimacy is closely connected to its accountability. They argue that an organisation can generate legitimacy through improving its performance, building stronger relationships with its constituencies, and increasing its transparency. Walton et al. (2016) argue that these definitions tend to "view legitimacy challenges in terms of technical deficiencies'. Critics argue that the focus on organisational accountability, performance and representativeness within these technical and practitioner perspectives often obscures much deeper and more political questions about legitimacy, and neglects the ways in which legitimacy is constructed and reproduced (Lister 2003; Walton 2013).

This paper views legitimacy as a political rather than a technical issue. It is a situated process that is embedded within and shaped by social and power relations. The work of writers such as Lister (2003) and Walton (2008, 2013), who view civil society legitimacy as something that is socially constructed, is particularly useful. This is largely because these authors contend that legitimacy relates to perceptions of different stakeholders about whether an organisation or its behaviour conforms to their values and expectations about civil society. These expectations are rooted within specific normative frameworks. Consequently, different constituencies (such as the national government, international donors and local communities) often have different expectations about civil society, and what constitutes a legitimate actor or behaviour. This means that organisations may be considered legitimate by some groups and not others. Legitimacy may even be directly contradictory. Being seen to possess legitimacy among one constituency may actually undermine an organisation's legitimacy in the eyes of another. For example, being seen to possess a high degree of legitimacy with the international community may result in an organisation being seen as less legitimate by domestic stakeholders such as the national government. Furthermore, each group will privilege certain kinds of legitimacy over others (see Table 1).

Broadly speaking there are four kinds of legitimacy: regulatory, pragmatic, normative and cognitive (Brown and Jagadananda 2007; Lister 2003). Regulatory legitimacy is produced through compliance with legal frameworks and regulatory requirements concerning civil society, including legislation covering the registration and governance of organisations as well as laws on related issues such as public protest. Pragmatic legitimacy is generated where an organisation is perceived to meet or represent the interests and demands of a specific constituency or community. Whereas normative legitimacy relates to whether an organisation is seen to meet social norms, values and standards about what civil society organisations can and should be doing, cognitive legitimacy is where organisations are seen as making sense and are accepted as part of the way things are within a particular social context (Lister 2003; Brown and Jagadananda 2007). Lister argues that different kinds of legitimacy may come into conflict with each other and she urges us to consider the power relations implicit in legitimisation processes by asking 'which legitimacy matters' and 'for whom?' (2003: 184). This paper will demonstrate that Lister's questions are 
Table 1 Types of organisational legitimacy

\begin{tabular}{|c|c|}
\hline $\begin{array}{l}\text { Regulatory } \\
\text { legitimacy }\end{array}$ & $\begin{array}{l}\text { Where an organisation is seen to be compliant with legal frameworks and regulatory requirements concerning civil society, } \\
\text { as well as all other laws governing a particular jurisdiction }\end{array}$ \\
\hline $\begin{array}{l}\text { Pragmatic } \\
\text { legitimacy }\end{array}$ & Where an organisation is perceived to meet or represent the interests and demands of a specific constituency \\
\hline $\begin{array}{l}\text { Normative } \\
\text { legitimacy }\end{array}$ & $\begin{array}{l}\text { Where an organisation is seen to meet social norms, values and standards about what civil society organisations can and } \\
\text { should be doing by different constituencies }\end{array}$ \\
\hline $\begin{array}{l}\text { Cognitive } \\
\text { legitimacy }\end{array}$ & $\begin{array}{l}\text { Where organisations are seen as making sense within larger societal narratives and structures, and are recognised, accepted } \\
\text { and even taken for granted as being part of the way things are within a particular social context }\end{array}$ \\
\hline
\end{tabular}

especially pertinent in violent and divided contexts where political space for civil society is under threat.

\section{Political Space for Civil Society in Violent and Divided Contexts}

Within the burgeoning policy literature on political space for civil society, civil society space is defined as 'the environment within which civil society operates' (United Nations Human Rights Council 2014: 1). These environments are either characterised as enabling or disenabling. Whereas enabling environments denote the presence of supportive conditions that allow civil society to grow and to flourish, disenabling environments indicate the presence of 'restrictive conditions... [which] make it harder for civil society groups to exist, function, grow and offer their best contribution to society' (Civicus 2013: 10). Transnational civil society networks and INGOs argue that space for civil society is shrinking around the world as governments, and sometimes non-state actors such as armed groups, impose restrictions on civil society, such as the imposition of legal and regulatory frameworks that constrain the creation and operation of civil society groups, or through arbitrarily arresting and detaining civil society activists and human rights defenders (ACT Alliance and CIDSE 2014; Carothers and Brechenmacher 2014; Civicus 2013; Trócaire 2012; World Movement for Democracy and INCL 2012).

Van der Borgh and Terwindt (2014) define political space for civil society as 'the very opportunities and threats that organisations or individuals experience in a political context, as well as the ways they use those opportunities' (van der Borgh and Terwindt 2014: 36). Consequently, political and operating space of particular organisations is 'not simply taken up... [but] is also made by these organisations and can be claimed or reshaped by NGOs themselves' (van der Borgh and Terwindt 2014: 37). Their study focuses on three factors that shape this space: the political context within which organisations are situated, the policies and actions of state and non-state actors that place restrictions on NGOs, and the particular characteristics of NGOs that can make them more vulnerable to these restrictions. They find that political space for civil society is 'not systematically repressed' and that some organisations are more vulnerable to pressures than others (van der Borgh and Terwindt 2014: 164). They discover that organisations that engage in claim-making against the state or work on issues considered to be sensitive or political issues are more likely to experience restrictions (van der Borgh and Terwindt 2014). In their own words:

Even though a number of NGOs faced strong stigmatisation, threats and even killings, many other informants argue that the political space actually increased in the past decades. This is also the case for organisations that are most vulnerable to pressures those making claims vis-à-vis other actors, such as the state, corporations or religious elites. Thus, even NGOs that touch on more sensitive topics do not necessarily experience pressures. Moreover, where they do experience pressures there are marked differences in the type of pressure and the intensity. (van der Borgh and Terwindt 2014: 164-165).

This paper argues that political space also relates to the individual and collective perceptions of civil society actors themselves (Beswick 2010), which are shaped by historical and contemporary experiences of government restrictions or of harassment and intimidation, as well as emotions and subjectivities, such as a fear of reprisals. These perceptions may influence the behaviour of activists and organisations, and the extent to which they are able to claim or reshape their political and operating space. Furthermore, these perceptions are not static, but are liable to fluctuate in relation to changes within the social and political landscape within which activists and organisations are situated. Perceptions of political space among activists are also affected by processes of legitimation and delegitimisation, which are situated within particular social and political landscapes and are highly context specific. In violent and divided settings such as conflict zones, or those places where political space for civil society is under threat, these 
processes are often highly politicised and the context within which they are situated can be extremely dynamic and unstable (Walton 2013).

The literature on civil society space highlights some specific issues relating to organisational and political legitimacy that may be faced by civil society organisations located in violent and divided contexts. The first set of challenges relates to legal and regulatory frameworks for civil society in violent and divided contexts. While good legislation and a supportive regulatory environment can improve civil society legitimacy, a poor or restrictive legislative framework can undermine it (Hayman et al. 2013, 2014). However, legislative frameworks in violent and divided contexts are often either weak, or place burdensome and sometimes arbitrary restrictions on civil society (ACT Alliance and CIDSE 2014; Civicus 2013; Trócaire 2012). An increasing number of governments have also introduced legislation that either prohibits or restricts foreign funding for civil society in recent years (Christensen and Weinstein 2013). Such legislation may be introduced for various reasons. Some national governments see organisations that receive foreign funding as more accountable to international donors than domestic constituencies, and use these concerns about local legitimacy to justify restrictions on civil society (see Wood 2016 on Kenya; Dupuy et al. 2015 on Ethiopia; Chahim and Prakash 2014 on Nigaragua). Organisations that receive foreign funding in violent and divided contexts often come to be associated with externally imposed agendas, and may be subject to 'powerful anti-NGO discourses' that 'are usually based on fears that NGOs are providing a surreptitious means for foreign governments to influence domestic politics' (Walton 2013: 28). Consequently, governments may also introduce such legislation in the hope of weakening groups that are thought to be capable of mobilising opposition to their regimes (Christensen and Weinstein 2013).

The second set of challenges relates to the highly politicised and extremely fluid and changeable nature of violent and divided contexts. Perceptions about which behaviours are legitimate are liable to change as the social and political landscape shifts during and after violent conflict. Byrne and Clem argue that postwar transitions represent particularly fluid and precarious moments where new rules of the game are negotiated. This involves important shifts in the kinds of politics that are considered legitimate and those that are rendered out of bounds' (2015: 225). Shifts in the social and political terrain during and after violence can have a profound effect on the legitimacy of civil society organisations and their political space. Walton finds that processes of legitimation and delegitimisation in conflict-affected environments 'are liable to fluctuation in relation to changes in the political climate and are likely to be instrumentalised by political actors' (2013: 19). This is because they are often linked to broader struggles for political legitimacy. In some contexts, where the political legitimacy of the ruling regime is contested, civil society organisations may be seen as part of the political opposition or representatives of foreign interests. This may lead Governments to view them as a potential alternative source of legitimacy, and even as a threat to state power and sovereignty (Wood 2016; van der Borgh and Terwindt 2014; Walton 2013).

\section{Conceptual Framework}

This paper draws on certain findings and arguments within the literature explored above to create a conceptual framework for examining why some organisations that work on human rights and democracy promotion issues in Burundi were subject to restrictions and others were not. The first is the assertion that civil society organisations may possess legitimacy in their own right, and challenge the political legitimacy of the government. This paper argues that in order to understand the relationships between legitimacy and political space for civil society, it is important to consider both organisational legitimacy and political legitimacy. Consequently, it will begin by examining the connections between the amount of legitimacy an organisation had and its political space, before exploring whether there is a link between an organisation's experience of restrictions and the extent to which it was seen to challenge the political legitimacy of the Burundian government.

The second finding that this paper draws on is that political space for civil society relates to multiple factors, including the political context within which organisations are situated, the policies and actions of state and non-state actors that place restrictions on civil society and the particular characteristics of organisations that can make them more vulnerable to these restrictions. This paper focuses on the third factor; the characteristics that make some organisations more prone to restrictions than others. There are a huge number of potential variables including organisational function, scale of operation, funding, leadership, values, personal networks, behaviour and approach to name but a few. This paper will focus on the characteristics that appear to be the most relevant in the Burundian case: organisational function (e.g. whether it engages in advocacy or service delivery), organisational behaviour (e.g. its approach to engaging with the state authorities) and organisational values (e.g. whether it is faith-based or secular). The paper considers how each of these factors relates to both organisational legitimacy and political legitimacy. It begins by examining how these factors affect the amount of normative, cognitive, and pragmatic 
legitimacy an organisation possesses. This is because legitimacy is often a matter of degree rather than something you either have or do not, and an organisation may have more of one form of legitimacy than another. The paper then explores how these factors affect the extent to which an organisation was seen to challenge the political legitimacy of the state.

The final argument within the existing literature that this paper draws on is that legitimacy is a social process. It is embedded within and shaped by social and power relations, and it can be produced and developed, or disputed and undermined. Legitimacy also relates to perceptions, which means that different constituencies may view the same organisation in different ways. This means that an organisation may have more normative, cognitive or pragmatic legitimacy in the eyes of one group of stakeholders that it does with another. In other words, legitimacy can be contested and contradictory. This is why the question 'which legitimacy matters and for whom?' is so important, especially in contexts where space for civil society is constrained. In contexts where civil society is under threat, it is likely to be the views of the individual or institution that is behind the restrictions-whether that is the government, a political party, the police, the army or a non-state armed group-that matter most when it comes to political space. Consequently, this paper focuses on the relationship between civil society organisations and the Burundian government, and how organisations that work on democracy promotion and human rights in Burundi are seen by the ruling elite. It also considers how organisations that faced restrictions were seen by the international community, and explores whether this reinforced or undermined their normative and cognitive legitimacy with the Burundian authorities, and the extent to which they were perceived to challenge the political legitimacy of the government.

\section{Legitimacy and Political Space for Civil Society in Burundi}

Burundi has endured several cycles of ethnic conflict and genocidal violence since it gained independence from Belgium in 1962 (Daley 2008; Lemarchand 1996, 2009; Uvin 1999, 2009; Watt 2008). In 1993, the assassination of Burundi's first democratically elected Hutu president precipitated a civil war that lasted for over a decade and resulted in the deaths of at least 300,000 people (Daley 2008; Uvin 2009). Peace negotiations led to the signing of the Arusha Peace and Reconciliation Accords in 2000, which provided for the establishment of a power-sharing government and multi-party elections, first held in 2005 and won by Pierre Nkurunziza and the CNDD-FDD.
Although the saliency of ethnicity declined in the postwar period, political divisions between the ruling party and opposition supporters have increased as have levels of political and everyday violence, especially around elections.

Prior to the 2015 elections, Burundi had a vibrant and active civil society with a diverse range of organisations working on a variety of issues. However, over the postwar decade (2005-2015), the government systematically targeted certain activists and organisations. Increasing pressures on civil society and opposition parties led international human rights organisations to claim that political space is shrinking in Burundi (Amnesty International 2014; Human Rights Watch 2010, 2012). Within the policy literature, shrinking space for civil society tends to be seen as a relatively recent phenomenon in Burundi, yet previous regimes have also placed restrictions on civil society and opposition parties, and dissent has often been met with violence and repression in the past *(Lemarchand 1996; Daley 2008). Relations between civil society and the Nkurunziza regime became increasingly confrontational around the 2010 elections, and deteriorated further around the 2015 elections. The government used a variety of strategies to limit political space for civil society groups in the run up to the 2015 elections including the introduction of restrictive legislation and the harassment and intimidation of activists. They also sought to impede the day to day operation of certain groups through disrupting meetings, refusing to meet with representatives, and limiting access to information that should be publically available (Amnesty International 2014). They tried to undermine the operation of more prominent civil society organisations through the establishment of pro-government groups or government-owned nongovernmental organisations (GONGOs).

Not all civil society organisations in Burundi have experienced these restrictions in the same way or to the same extent. The existing policy literature on political and operating space for civil society argues that organisations that work on issues considered to be political or sensitive within a society, such as human rights and democracy promotion tend to experience greater restrictions (ACT Alliance 2011; ACT Alliance and CIDSE 2014; Civicus 2013; Trócaire 2012). In the run up to the 2015 elections the Burundian Government targeted organisations that work on democracy and human rights. However, when asked how they would describe their relationship with the Government, individuals that worked or volunteered for organisations working on human rights and democracy promotion gave a mixed response. In total, thirteen of the organisations that participated in this study explained that they work on issues related to democratisation and human rights (see Table 2). Some of the topics that they worked 
Table 2 Groups working on human rights and democracy promotion in Burundi

\begin{tabular}{|c|c|c|c|c|c|}
\hline Group & $\begin{array}{l}\text { Primary } \\
\text { domain }\end{array}$ & $\begin{array}{l}\text { Organisational } \\
\text { functions }\end{array}$ & $\begin{array}{l}\text { Organisational behaviour (approach to } \\
\text { advocacy) }\end{array}$ & $\begin{array}{l}\text { Organisational values (faith- } \\
\text { based or secular) }\end{array}$ & $\begin{array}{l}\text { Experience of direct } \\
\text { restrictions }\end{array}$ \\
\hline 1 & Human rights & $\begin{array}{l}\text { Monitoring } \\
\text { Advocacy } \\
\text { Service delivery }\end{array}$ & Confrontational & Faith-based & Yes \\
\hline 2 & $\begin{array}{l}\text { Peacebuilding } \\
\text { Human rights }\end{array}$ & $\begin{array}{l}\text { Socialisation } \\
\text { Advocacy } \\
\text { Research }\end{array}$ & Non-confrontational & Secular & No \\
\hline 3 & $\begin{array}{l}\text { Peacebuilding } \\
\text { Human rights }\end{array}$ & $\begin{array}{l}\text { Mediation } \\
\text { Advocacy } \\
\text { Socialisation } \\
\text { Social cohesion } \\
\text { Monitoring }\end{array}$ & Non-confrontational & Faith-based & No \\
\hline 4 & $\begin{array}{l}\text { Peacebuilding } \\
\text { Human rights }\end{array}$ & $\begin{array}{l}\text { Advocacy } \\
\text { Socialisation } \\
\text { Service delivery }\end{array}$ & Non-confrontational & Faith-based & No \\
\hline 5 & $\begin{array}{l}\text { Peacebuilding } \\
\text { Human rights }\end{array}$ & $\begin{array}{l}\text { Advocacy } \\
\text { Research } \\
\text { Mediation }\end{array}$ & Non-confrontational & Secular & No \\
\hline 6 & $\begin{array}{l}\text { Democracy } \\
\text { promotion }\end{array}$ & $\begin{array}{l}\text { Advocacy } \\
\text { Monitoring } \\
\text { Socialisation }\end{array}$ & Confrontational & Secular & Yes \\
\hline 7 & $\begin{array}{c}\text { Human rights } \\
\text { Democracy } \\
\text { promotion }\end{array}$ & $\begin{array}{l}\text { Advocacy } \\
\text { Socialisation }\end{array}$ & Confrontational & Secular & Yes \\
\hline 8 & $\begin{array}{l}\text { Human rights } \\
\text { Democracy } \\
\text { promotion }\end{array}$ & $\begin{array}{l}\text { Advocacy } \\
\text { Socialisation }\end{array}$ & Confrontational & Secular & Yes \\
\hline 9 & $\begin{array}{l}\text { Democracy } \\
\text { promotion }\end{array}$ & $\begin{array}{l}\text { Monitoring } \\
\text { Mediation } \\
\text { Advocacy }\end{array}$ & Non-confrontational & Secular & No \\
\hline 10 & Human rights & $\begin{array}{l}\text { Advocacy } \\
\text { Socialisation } \\
\text { Monitoring } \\
\text { Service delivery }\end{array}$ & $\begin{array}{l}\text { Mostly non-confrontational, } \\
\text { occasionally confrontational }\end{array}$ & Secular & Yes \\
\hline 11 & $\begin{array}{l}\text { Peacebuilding } \\
\text { Human rights }\end{array}$ & $\begin{array}{l}\text { Mediation } \\
\text { Socialisation } \\
\text { Advocacy } \\
\text { Social cohesion } \\
\text { Monitoring }\end{array}$ & Non-confrontational & Faith-based & No \\
\hline 12 & $\begin{array}{l}\text { Peacebuilding } \\
\text { Human rights }\end{array}$ & $\begin{array}{l}\text { Mediation } \\
\text { Socialisation } \\
\text { Social cohesion }\end{array}$ & Non-confrontational & Faith-based & No \\
\hline 13 & $\begin{array}{l}\text { Democracy } \\
\text { promotion }\end{array}$ & $\begin{array}{l}\text { Monitoring } \\
\text { Research } \\
\text { Advocacy } \\
\text { Socialisation }\end{array}$ & Non-confrontational & Secular & No \\
\hline
\end{tabular}


on included electoral violence, torture and other human rights abuses, corruption and participatory governance, democratic institutions and public freedoms. Of these thirteen organisations, five said that they had experienced direct restrictions while the other eight had not. Here, direct restrictions refer either to the harassment and intimidation of activists by the security services or militias associated with political parties such as the Imbonerakure, or government interference in the internal functions of organisations. The latter includes banning or disrupting meetings, prohibiting decision makers from meeting with representatives of certain organisations, blocking access to information or using pro-government groups to undermine organisations.

The five organisations that had experienced direct restrictions tended to be prominent organisations that conducted advocacy on democracy and human rights at the national level. These organisations were often located in Bujumbura, had limited connections to grassroots communities and were heavily dependent on international and multilateral funding, although some associations did receive a modest income from membership subscriptions. Many of these groups also had prominent and vocal leaders. Speaking about their relations with the authorities, a male activist from one of these organisations explained that 'there is a good collaboration but sometimes it is not easy... sometimes there is a bad relation, but it depends on the issue we are working on' (Interview with activist from Group 1, 31 March 2015). A female activist working with another of these organisations described their relation with the authorities as 'one of strained collaboration' because they are considered to be 'part of a group of organisations that are not really tolerated by the Government' (Interview with activist from Group 10, 30 September 2014). Many of those interviewed also reported receiving threatening phone calls or experiencing other forms of harassment and intimidation.

The organisations that had not experienced direct restrictions were far more diverse. Notably, they included several faith-based organisations. However, it is important to note that not all of the organisations in this group are faith-based. Organisations that did not experience restrictions tended to have much stronger connections to grassroots communities as well as influential institutions such as the Catholic Church or the Episcopalian and Mennonite churches. Although they also relied on funding from international donors, some had strong domestic resource mobilisation capacities as well. These organisations also worked on issues such as human rights, participatory governance and democratisation, but this was often a secondary focus and their primary work often concerned issues such as reconciliation and non-violent conflict resolution. A male activist from a large faith-based association that did a lot of work on human rights and governance within communities described their relationship with the authorities 'as one of mutual aid and assistance, that is, one of contact and consultation' (Interview with activist from Group 4, 30 March 2015). The male leader of another faith-based association stated that their organisation was 'respected throughout the country' and explained that "when we invite the authorities to our activities, they come. They also invite us to participate in activities organised by the administration' (Interview with activist from Group 11, 19 March 2015). Among the secular associations included in this group were two organisations that conducted research on human rights and democracy promotion, and a network that monitored these issues at the grassroots level. A male respondent from one of these organisations explained that they are not targeted in the same way as other groups that work on issues such as good governance, democratisation and human rights, and that they have a more constructive relationship with the authorities: 'there are no problems. We participate in activities which we are requested to participate in that are organised by the government... When we organise activities, [government] representatives will participate in them. (Interview with activist from Group 13, 25 September 2014).

The different experiences among the human rights and democracy promotion community in Burundi raise a number of important questions, one of which is why some organisations were able to work on these issues without experiencing direct restrictions, while others were subject to harassment and intimidation. The remainder of this section will consider how both organisational legitimacy and political legitimacy affected the political space of individual civil society groups in Burundi. It will look at how three main characteristics, organisational function, approach to engaging with authorities and organisational values, relate to both the degree of legitimacy an organisation possessed and the extent to which it was seen to challenge the political legitimacy of the regime.

\section{Organisational Legitimacy}

Organisations that appear to have a lower degree of organisational legitimacy (and more specifically their pragmatic, normative and cognitive legitimacy) in the eyes of the Burundian regime were more vulnerable to restrictions. Organisational function, behaviour and values all appear to affect the degree of legitimacy an organisation possessed, but cannot on their own explain why one organisation experienced direct restrictions and another did not. Each of these characteristics will be considered in turn, beginning with organisational function. 


\section{Organisational Function}

Organisations working on human rights and democracy promotion in Burundi engaged in a range of functions, from monitoring and denouncing human rights violations, corruption and electoral violence, to engaging in socialisation activities and human rights education and the provision of services to victims of human rights abuses. Much of the policy literature on political space for civil society argues that organisations that engage in advocacy or claimmaking on issues that are considered to be sensitive or political are more likely to experience pressures than those engaged in activities like service delivery for example (ACT Alliance and CIDSE 2014). All the organisations that reported experience of direct restrictions engaged in advocacy on sensitive or political issues in Burundi, such as corruption, human rights abuses, constitutional issues and democracy promotion. In interviews, representatives of these groups regularly expressed the view that the government does not understand what they do, which suggests that they lack normative and cognitive legitimacy in the eyes of the authorities. As one male campaigner said: 'the Government needs to better understand the role of civil society, we need to explain it to the government and educate them about its advantages' (Interview with activist from Group 7, 27 March 2015). While the government recognises the provision of services as an admissible function of civil society, it does not see advocacy or campaigning, especially on issues that it considered to be sensitive such as corruption or human rights abuses, as legitimate behaviour.

Many of the organisations in Burundi that had experienced direct restrictions described themselves as "watchdogs', whose primary role was to hold the government to account (Interview with male activist from Group 8, 23 March 2015). While this was not seen as an appropriate or legitimate function by the Burundian government, it was widely recognised and supported by international nongovernmental organisations as well as multilateral institutions and bilateral donors with whom they enjoyed strong normative and cognitive legitimacy. All the organisations targeted by the Burundian authorities received significant support from the international human rights community, both in the form of funding and what could be called political support. International organisations would frequently intervene on behalf of these civil society organisations, making statements in the Burundian press as well as direct appeals to the Burundian government. They also raised their concerns at an international level, making statements at the UN Human Rights Council and in other multilateral forums, and with their own governments. This is what Keck and Sikkink (1998) have termed the 'boomerang effect', where national groups use transnational advocacy networks to appeal to people in other countries to put pressure on their own government to challenge pressures and restrictions. This is an important strategy that was used by many of the organisations that experienced restrictions and the international organisations that supported them. However, the support of the international community may have further undermined the normative and cognitive legitimacy of these groups in the eyes of the Burundian government, who would refer to them as foreign agents. However, many of the groups that did not experience direct restrictions also engaged in advocacy on sensitive issues such as human rights and democracy promotion and received support from the international community. This suggests that organisational function is not on its own a sufficient explanation, although it is part of the story.

\section{Organisational Behaviour}

Organisational behaviour, or more specifically, the approach to advocacy and claim-making that an organisation adopts, seems to have a greater bearing on whether an organisation experienced restrictions or not. This is supported by Van der Borgh and Terwindt (2014), who find that claim-making organisations that adopt confrontational strategies are more likely to experience pressures. Organisations that involved in advocacy and claim-making on human rights and democracy promotion in Burundi adopted a number of different strategies. Organisations that did not experience direct restrictions often adopted a less confrontational approach. A male activist working for one of these organisations was even reluctant to use the word advocacy to describe what they do.

Interviewer: Is there an advocacy component to the project? Respondent: Yes, but we use a different word, not advocacy. This is the word that [our donor] uses. Interviewer: You use a different word? Respondent: It's a Kirundi word, it's similar to advocacy and lobbying but a bit different. It means trying to convince. So we try to convince administrators to do something for the benefit of the population...Interviewer: So it's less strong than advocacy, less confrontational? Respondent: Yes. (Interview with activist from Group 11, 27 March 2015)

Another activist working for the same organisation described their approach to advocacy as 'diplomatie douce', which roughly translates as soft diplomacy. He explained how this approach differs from that used by other civil society groups: 
We have civil society organisations for whom advocacy is central to their work. They publish, they speak on the radio, they write these memorandums attacking the president and decision makers. At [our organisation] we use what we call 'diplomatie douce'. We approach decision makers and we ask to meet them... We ask for a meeting, we approach them, we explain the change we are looking to see, we share our experience with them, and ask them to accept our change. The meetings are often informal. We don't publish in the media (Interview with activist from Group 11, 18 March 2015).

Grounding advocacy in research was also important for many civil society organisations that sought to adopt a more cooperative approach. A male activist working for a peacebuilding and human rights group that works at the national and the local level explained how research-based advocacy was essential to protecting their political and operating space:

Most of the time the government sees human rights NGOs as people who are there to say whatever they want, whenever they want to say it, without bringing evidence. That's why we have invested a lot in research to make sure our advocacy work is also evidence based. This has even been a strategy for our own security because when you really invest in research, you collect data, you collect accurate information. Once you bring it [to the government] people will not tend to play a defensive game. (Interview with activist from Group 2, 09 April 2015).

Other groups also used research-based advocacy to create spaces for engagement with the government. A female activist working with a peacebuilding organisation that also works on democracy promotion issues explained how they include decision makers in their research: 'We have a steering committee, and this is made up of decision makers, e.g. presidents of political parties, minister of the interior. We keep them informed and seek their advice on issues.' (Interview with activist from Group 5, 07 April 2015).

Many of the organisations that did not experience restrictions also sought to build the capacity of communities to engage with local authorities in a constructive manner. A male activist working with a faith-based organisation explained that: "we support communities to work with the local administration, identify problems and try to talk to the local administration about them. They try to propose joint solutions and offer their help' (Interview activist from Group 11, 30 March 2015). A male community-based activist working with a different organisation gave an example of their anti-corruption work within a particular community. Members of the committee recognised that there was a problem with corruption at the local market, which meant that the traders were refusing to pay their taxes and the authority was losing out on much needed revenue. Their intervention helped to solve a longrunning conflict between market traders and government officials, and also improved relations between the organisation and the local authorities.

We went into the market to encourage traders to begin paying taxes, and we also worked with the authorities to reduce corruption. We engaged in awareness raising with the authorities and the traders to try to change perceptions, and show that reducing corruption would lead to an increase in taxation which would benefit both parties... At the start our work wasn't appreciated [by the local authorities], but our perceptions of each other changed following our work in the market. Our relations improved and now we are really appreciated (Interview with activist from Group 3, 17 March 2015).

This suggests that the work of the group led to the production of pragmatic legitimacy in the eyes of the local authorities, which enabled them to conduct advocacy on what can be an extremely sensitive issue in Burundi, without experiencing restrictions.

Organisations that faced direct restrictions often pursued a more confrontational approach to claim-making. A male activist working for a peacebuilding and human rights organisations that had not experienced direct restrictions was critical of the confrontational approach pursued by some organisations:

There are some who think that civil society must systematically oppose the government, that a civil society organisation is one that systematically opposes the government. That's not really my point of view. It's difficult to influence the revision of laws, it's difficult to influence the revision of policies, it's difficult to conduct campaigns. The government is not persuaded in this way. It's very difficult. If the government don't see any wish for collaboration, they'll never accept your proposition and they'll treat you as an opponent. And it's the population who lose out, because if unpopular laws stay in place, there is anger. (Interview with activist from Group 2, 29 September 2014).

Although the use of confrontational strategies makes organisations more vulnerable to restrictions, many of the human rights activists interviewed felt that that they had no choice but to pursue a confrontational approach. A male activist working for a high-profile human rights organisation said: 
When we do a study, and we have recommendations, we'll approach the relevant Government officials. But they don't want to meet us. So we have no choice but to denounce. We write letters, but they don't respond. They refuse to meet us. They refuse our demands. (Interview with activist from Group 7, 27 March 2015).

Consequently, human rights activists often turn to the media to provoke a response from the government. As a male activist from another organisation explained: 'when you have made your statement through the media and you are tough... they will respond' (Interview with activist from Group 8, 23 March 2015). Limited opportunities for more constructive engagement with the authorities meant that organisations felt that they had to pursue more confrontational strategies in order to change their operating environment and challenge restrictions. Clearly, the relationship between an organisation's approach to advocacy and their experience of restrictions and pressures is not a straightforward one. Organisations that lacked political space felt like they have no option but to use more confrontational approaches, which put them at increased risk of pressures. Whereas organisations that had access to public authorities and consequently had a greater degree of political space were able to pursue less adversarial approach to claim-making. However, their approach to advocacy does appear to have influenced the amount of organisational legitimacy they had with the regime. Organisations that pursued confrontational approaches tended to have less normative and cognitive legitimacy in the eyes of the government, while those that pursue more constructive approaches tended to have more normative and cognitive legitimacy, and sometimes even pragmatic legitimacy, with the authorities.

\section{Organisational Values}

Organisational values also appear to have a bearing on the degree of normative and cognitive legitimacy a group had with the Burundian regime and consequently, their political space. Among the organisations that conducted advocacy on sensitive issues, but did not experience direct restrictions were a significant number of faith-based organisations, while most organisations that were targeted by the government were secular groups. Faith-based organisations tended to conform more to expectations among the authorities about what civil society groups should be and do, and had stronger connections with local communities because of their relationships with local churches. These organisations derived cognitive legitimacy from their faithbased identity and their relationship with religious institutions such as the Catholic Church, the Quakers or the
Mennonite Church. A male one activist working for a faithbased organisation explained, 'The role of the church is very important. It has an important place in our society... [It means that] we have a lot of credibility among the population' (Interview with activist from Group 3, 10 March 2015). This was because the majority of the Burundian population, including the ruling elite, are Christian, and recognised and accepted the values of faithbased organisations. Another important source of normative and cognitive legitimacy with the authorities for those organisations that did not experience direct pressures was their independence and political neutrality. Many activists I spoke to felt that their relationship with faith-based institutions reinforced perceptions of independence. As a male activist explained, their relationship with the Church is one reason why the authorities appreciate us. We are seen as a neutral actor working for the benefit of the population. Our neutrality is very important here' (Interview with activist from Group 3, 17 March 2015).

However, not all organisations that escaped direct restrictions were faith-based, and one of the organisations that did experience direct restrictions was a faith-based group. This suggests that it is not being faith-based per se that protects organisations from restrictions, but the extent to which their values affect the degree of normative and cognitive legitimacy an organisation possesses with the Burundian authorities. This perception is not fixed, something that is evidenced by the changing position of the Catholic Church in Burundi around the 2015 elections. The Catholic Church spoke out against the President's decision to run for a third term, and withdrew its support for the elections, stating that it 'cannot support an election riddled with shortcomings'. 2 The Government responded by taking an increasingly critical and even antagonistic approach towards the Church in the months following the elections. In March 2016, the President of the National Assembly criticised the Church for playing 'a purely political, not spiritual role' and said that the Government would not engage with 'sponsors of terrorism' and 'insurgent individuals who participated in the destabilisation of democratically elected institutions'.3 Many faith-based

\footnotetext{
2 Bishop Gervais Bashimiyubusa quoted by in article by Al Jazeera (28 May 2015) 'Catholic church drops backing for Burundi election: Church withdraws support to upcoming presidential and parliamentary elections marred by violence against the president.' Available online at: http://www.aljazeera.com/news/2015/05/catholic-churchdrops-backing-burundi-election-150528084805057.html (Accessed 31 August 2016).

3 Pascal Nyabenda quoted by Jonathon Luxmoore (7 April 2016) 'Burundi official accuses Church of 'sponsoring terrorism' as crisis engulfs the country' published in the Catholic Herald. Available online at http://www.catholicherald.co.uk/news/2016/04/07/burundiofficial-accuses-church-of-sponsoring-terrorism-as-crisis-engulfs-thecountry/ (Accessed 31 March 2016).
} 
organisations struggled with the politicisation of the Church in the wake of the anti-third term protests, which challenged their political neutrality and their cognitive and normative legitimacy. Speaking in March 2015, one activist who worked with a catholic civil society organisation said that: 'the Catholic Church opposes the third term of the President, so at the moment the relationship between the Church and the Government is not good.' (Interview with activist from Group 3, 10 March 2015). Many were concerned about how the changing position of the Church would affect their relationship with the government. The leader of another faith-based organisation said, "we are attached to the Catholic Church so the challenges we face are the same as those of the Catholic Church' (Interview with female activist from Group 4, 22 September 2014).

To summarise, all the organisations that work on human rights and democracy promotion issues in this study were involved in advocacy or claim-making activities of some sort, yet not all of them experienced pressures. The authorities tended to target those that pursued confrontational advocacy strategies, while those who adopted a less antagonistic approach to advocacy were less likely to experience restrictions. Many of the organisations that experienced pressures described themselves as 'watchdogs', and did not fit with what the authorities felt that civil society organisations should be and do. Organisations that faced restrictions tended to have less normative and cognitive legitimacy in the eyes of the Burundian authorities, while those that were less vulnerable to pressures tended to have a high degree of normative, cognitive and even pragmatic legitimacy with the government. This is not static and is liable to change as the social and political context evolves - as evidenced by changing position of the Catholic Church, who came under attack as they took a more critical and outspoken approach to engagement with the authorities. Furthermore, organisational legitimacy is often contradictory and contested. Organisations that lacked normative and cognitive legitimacy with the Burundian government often had a high degree of normative and cognitive legitimacy among international organisations, who provided them with financial and political support. However, their close relationship with the international community contributed to the unfounded perception that these organisations were foreign agents and further undermined their legitimacy with the Burundian regime.

\section{Political Legitimacy}

There is another explanation for why some organisations experienced restrictions and others did not. Evidence from this study suggests that it is not just the amount of legitimacy these organisations possess, but the extent to which they were perceived to challenge political legitimacy of the regime that mattered. Van Der Borgh and Terwindt (2014) argue that although organisations that engage in claimmaking on sensitive issues are more vulnerable to pressures, they rarely experience them evenly because 'pressures are not simply the result of the fact that NGOs make claims, but depend on the extent to which they are perceived to impinge on the interests of different kinds of elites' (2014: 168). This argument is supported by Walton (2013), who contends that processes of legitimation and delegitimation are often linked to broader struggles for political legitimacy in contexts where the power and authority of government elites is contested. He argues that governments whose own political legitimacy is challenged may seek to weaken perceived opposition to their regime through undermining the legitimacy of those civil society groups they see as a threat.

This appears to be the case in Burundi, where the political legitimacy of the President and his regime has been challenged repeatedly in recent years. At no time was this more acute than at the 2015 elections, where President Nkurunziza decided to stand for what many saw as an unconstitutional third term. His decision to seek re-election was challenged by a wide variety of institutions including opposition parties, some civil society groups, the Catholic Church and the international community. Mass demonstrations erupted on the capital, Bujumbura, in the days following the announcement that Nkurunziza would pursue a third term. Despite repeated calls from civil society leaders for the protests to remain peaceful, the demonstrations turned violent in the face of brutal police repression. An attempted coup d'etat in May 2015 exacerbated the situation and clashes between protesters and the police escalated as the Burundian government sought to crush what it described as an 'insurrection'. The Catholic Church in Burundi openly criticised the decision of the President to run for a third term, and withdrew its support for the election. The international community also criticised Nkurunziza, and institutions such as the EU suspended their financial support to the regime.

Restrictions on civil society increased in the months before and after the 2015 elections. These restrictions were largely targeted at groups that were part of the civil society campaign that sought to prevent the Burundian President from standing from for an unconstitutional third term. The campaign, which was known as the Stop the Third Term! Campaign, was launched in January 2015 and played an important role in organising the first protests that took place in April 2015. A male activist described it as 'the most important, actually, the most dangerous, the most striking action that we have undertaken as civil society' (Interview with activist from Group 8, 23 March 2015). The campaign argued that the decision of the President to 
run for a third term violated the Arusha Peace and Reconciliation Agreement, upon which the foundations of the postwar Burundian state rest. In doing so, the organisations that participated in this campaign were seen to directly challenge the authority and legitimacy of the President.

Many of the groups and activists that participated in the anti-third term campaign were already regarded as political opponents by the Burundian regime. All the organisations that I spoke to who reported experiencing direct restrictions said that the government saw them as close to or even part of the political opposition in Burundi. A male activist described his organisation's relationship with the authorities as "not that close, or that good...because we are counted as part of the opposition by them' (Interview with activist from Group 8, 23 March 2015). A male respondent from another organisation explained that, "[the authorities] refuse to collaborate. Ministers are forbidden to meet with members of [our organisation]. They accuse us of working with the opposition' (Interview with activist from Group 7, 27 March 2015). When asked whether he had experienced any harassment, one activist replied that he had not because his organisation was "not on the list of civil society organisations, of "dangerous" ones' (Interview with activist from Group 9, 18 March 15). He explained that the authorities were interested in only a small number of organisations that they considered to be close to the formal political opposition in Burundi:

Anyone who challenges the government, anyone who brings in a different point of view is considered as an opponent. It is to do with the maturity of the democracy and our capacity to accept a different, a contradictory view. So whoever is saying something different is viewed as an opponent by the government, which is of course not true. (Interview with activist from Group 9, 18 March 2015)

It appears that confrontational behaviour and adversarial strategies adopted by these groups not only undermined perceptions of normative and cognitive legitimacy with the authorities, but also reinforced the unfounded view that were either working with or for the political opposition in Burundi and were challenging the political legitimacy of the regime. Restrictions on these organisations increased as the government came under sustained pressure both from institutions within the country and from international actors.

During this time, the government actively used labels such as 'political opposition' and even 'insurgents' and 'terrorists' to discredit organisations that it viewed as a threat to its own political authority and legitimacy. Anticivil society discourses such as these were one of the principal tactics that the government used to undermine the organisational legitimacy and political space of organisations in the run up to the 2015 elections. The use of shadow organisations, or government-owned nongovernmental organisations (GONGOs) as they are more commonly known, to undermine outspoken civil society activists also became a significant feature of the Burundian context in the years leading up to the 2015 elections. Many of the groups that had experienced restrictions explained that they have a parallel pro-government organisation that shadows their work, which often has a similar name or acronym to their organisation. A male representative from a leading human rights group explained how these parallel or shadow organisations operated, and how they affected their work:

When we release a declaration, they will release a contradictory declaration. They will say [our organisation] advocated this or [our organisation] said this and it's not true. It's extremely dangerous because its purpose is to discredit civil society actions, sometimes portraying us to be the voice of the opposition, or to be funded by the west in order to destabilise the regime. This is a big issue. (Interview with activist from Group 8, 23 March 2015).

Shadow organisations were part of a broader strategy to stigmatise more prominent organisations by challenging their actions, contradicting their statements and spreading anti-civil society discourses which portray human rights organisations as either part of the political opposition or as foreign agents.

Another tool deployed by the Burundian regime to undermine organisations was the use of suspensions and bans, which targeted their regulatory legitimacy. Regulatory legitimacy is produced through compliance with legal frameworks and regulatory requirements concerning civil society, including legislation covering the registration and governance of organisations as well as laws on related issues such as public protest (Lister 2003; Brown and Jagadananda 2007). In 1992, the Burundian government introduced a legal and regulatory framework for civil society that provided for the creation of non-profit organisations as legal entities. ${ }^{4}$ All associations working on democracy promotion and human rights fell within the purview of this law, and those that were registered with the interior ministry and complied with provisions outlined within the legal and regulatory framework were considered to have regulatory legitimacy by the authorities. However, in 2009, the Interior Minister suspended one of the

\footnotetext{
${ }^{4}$ Republique du Burundi, 'Décret-loi n¹/11 du 18 avril 1992 portant cadre organique des associations sans but lucratif (ASBL)'. See Niyonkuru (2011) 'Defending Civil Society: Report on Laws and Regulations Governing Civil Society Organizations in Burundi', published by World Movement for Democracy for an analysis of the legal framework governing civil society in Burundi.
} 
country's leading human rights organisations. The ban, which was eventually lifted in 2011, was introduced after the organisation's leader publically implicated the government in killing of an anti-corruption campaigner, although the Interior Minister claimed at the time that it related to technical problems with the organisation's membership. ${ }^{5}$ In October 2016, the government banned five of the most prominent human rights associations in Burundi, all of which were involved in the Stop the Third Term! Campaign that organised the protests against the regime in 2015. Almost a year earlier, the government suspended the activities of ten civil society groups and a few days before suspensions were issued, demanded that national banks freeze the accounts of the organisations concerned, as well as those of three high-profile activists. ${ }^{6}$ In December 2016, the government went a step further and introduced a new law governing civil society, which makes it easier for the regime to undermine the regulatory legitimacy of organisations. The law requires organisations to renew their registration every 2 years. Groups also require approval from the relevant government department for all their activities, or face sanctions such as the closure of their offices and suspension of their activities.

To summarise, organisations that the government perceived as a threat to its own political authority and legitimacy were more likely to experience pressures. Many of the organisations that reported restrictions said that they were seen as part of or close to the political opposition by the government, and were part of the coalition that campaigned to stop the President standing for a third term. Anti-civil society discourses, shadow organisations and suspensions were all part of a broader strategy adopted by the Burundian Government to discredit these organisations. These tactics were used to undermine the normative, cognitive and even regulatory legitimacy of organisations that regime saw as a threat to its political authority and legitimacy. The restrictions increased and the rhetoric used by the regime became harsher, as domestic and international pressure on the government escalated in the run up to and following the poll. Those organisations and individuals that participated in or supported the demonstrations were

\footnotetext{
5 Human Rights Watch (1 February 2011) 'Burundi: Lifting Ban on Activist Group a Positive Step: Government Should Do More to Promote Freedom of Association'. Available online at: https://www. hrw.org/news/2011/02/01/burundi-lifting-ban-activist-group-positivestep. (Accessed 30 August 2016).

${ }^{6}$ Ministerial Ordinance No 530/1547 of 23 November 2015; Statement by EHAHRDP, APRODH, ACAT-Burundi, FOCODE, FORSC and RCP (23 November 2015) 'Burundi: Soon there will be no human rights defenders left'. Published by East and Horn of Africa Human Rights Defenders Project (EHAHRDP). Available online at: https://www.defenddefenders.org/2015/11/burundi-soon-there-willbe-no-human-rights-defenders-left-burundi-bientot-il-ny-aura-plusde-defenseurs-des-droits-de-lhomme/ (Accessed 25 August 2016).
}

labelled as 'insurgents', 'rebels' and 'terrorists' in an attempt to justify undue restrictions on civil society and even the use of violence. Some groups were banned, and many activists were forced to flee the country for their own safety. As their organisational legitimacy with the government declined, the normative and cognitive legitimacy of these organisations among the international community either remained constant or even increased, something that further emphasises the contested and contradictory nature of legitimacy. A handful of prominent human rights activists who had sought to hold the regime to account and were targeted by the Burundian authorities as a result received prominent international awards in the months and years following the protests. The most high-profile example is Pierre Claver Mbonimpa, an outspoken human rights defender who was awarded the 2016 Alison des Forges Award for Extraordinary Activism, after he had been jailed by the Burundian regime because of his work in 2014 and had narrowly survived an assassination attempt in 2015.

\section{Conclusion}

Restrictions on civil society are nothing new in Burundi, but they increased in the run up to the 2015 elections leading many observers to claim that political space in Burundi was shrinking. However, not all civil society organisations in Burundi experienced these restrictions in the same way, and some were more vulnerable to government pressures than others. The policy literature on civil society space argues that organisations that engage in claim-making on issues considered to be sensitive or political, such as human rights or democracy promotion, are more likely to experience restrictions. While the government targeted organisations that worked on democracy and human rights, not all groups that work on these issues faced restrictions and pressures. This paper sought to establish why this is the case, and in doing so build a deeper and more nuanced understanding of the connections between legitimacy and political space for civil society in violent and divided contexts such as Burundi.

It finds that organisations that had a higher degree of organisational legitimacy with the authorities were less likely to be targeted, and those with a lower degree of organisational legitimacy (and more specifically less pragmatic, normative and cognitive legitimacy) in the eyes of the Burundian regime were more vulnerable to restrictions. Organisational function, values and behaviour all appear to affect the degree of legitimacy an organisation possesses, but cannot on their own explain why one organisation experienced direct restrictions and another did not. For example, many of the organisations that had not experienced restrictions were faith-based, but this in itself 
does not appear to explain why these groups were not targeted. Rather these organisations tended to have a high degree of pragmatic, normative and cognitive legitimacy in the eyes of the Burundian authorities, and their faith-based identity contributed to production of this legitimacy. Groups that were not faith-based developed their normative, cognitive and pragmatic legitimacy with the authorities in different ways. Some generated pragmatic legitimacy through finding practical solutions to community problems that also benefited local authorities. Others increased normative legitimacy by involving decision makers in the work of the organisation, so that they had a better understanding of what the group did and why.

The connection between organisational behaviour and political space is stronger. The paper found that the Burundian government tended to target those organisations that pursued confrontational advocacy strategies, while those who adopted a less antagonistic approach to advocacy were less likely to experience restrictions. An organisation's approach to advocacy also affected both its organisational and political legitimacy. Those organisations who often described themselves as 'watchdogs' did not fit with what the authorities thought civil society organisations should be and do, and the confrontational advocacy strategies pursued by these organisations also reinforced the unfounded perception that these groups were connected the political opposition in Burundi. Consequently, it appears that these groups were targeted because the ruling elite viewed them as a threat to the political authority and legitimacy of the government. Restrictions on these groups increased as the regime came under sustained criticism from inside and outside the country in the run up to the 2015 elections. Many of the organisations that experienced restrictions were part of the civil society coalition that sought to prevent the President standing for an unconstitutional third term.

In this context, the assertion that a particular civil society group is part of the political opposition, a foreign agent or even a terrorist group, becomes a deliberate political tactic that was actively used by the government to discredit that organisation. This was part of a broader strategy to undermine the regulatory, normative and cognitive legitimacy of organisations that the regime viewed as a threat, which included the use of anti-civil society discourses, shadow organisations, organisational suspensions and bans. The government used these labels to justify the imposition of restrictions on certain organisations, and even the use of physical violence against activists and their families. While these groups had limited legitimacy in the eyes of the Burundian authorities, they retained a high degree of normative and cognitive legitimacy with the international community, particularly transnational human rights groups that provided them with financial support and political solidarity. However, legitimacy is often contested and contradictory, and strong organisational legitimacy among the international community may have further undermined their legitimacy with the Burundian authorities, who would often refer to these organisations as foreign agents.

What do these findings mean for policy and practice, specifically organisations working in violent and divided contexts such as Burundi and the international organisations that support them? First, they may help practitioners establish which organisations are more likely to be targeted by a regime: those organisations that have less organisational legitimacy in the eyes of the authorities, and are seen to challenge the political authority and legitimacy of the ruling elite. In the case of Burundi, this meant organisations who conducted advocacy on claim-making activities on sensitive topics such as corruption, human rights abuses and constitutional issues using confrontational strategies. Once it becomes easier to identify at-risk organisations, it becomes easier to target support to those that need it most. Second, the findings of this study may also help practitioners support organisations that experience pressures to manage their legitimacy and protect their political space. They emphasise just how important it is to be aware of how different constituencies perceive an organisation, and consider whose views matter most when it comes to protecting political and operating space. There may be steps an organisation can take to build and reinforce its legitimacy with different stakeholders, such as adopting advocacy strategies that are less confrontational and generate pragmatic legitimacy. However, building and developing organisational legitimacy is a complicated and lengthy process. Legitimacy relates to perceptions, which once they have been established are unlikely to change overnight. Managing organisational legitimacy is extremely complex and it may involve trade-offs; for example, increasing legitimacy with one constituency may diminish it among another.

Furthermore, as this research and other studies have shown, processes of legitimation and delegitimation are embedded within and affected by the broader social and political environment and the power relations that shape and sustain it. Paradoxically, activists may feel that the only way to challenge and transform social and power relations in violent and divided societies may be through the use of confrontational advocacy strategies that challenge the political authority and legitimacy of the regime head on. In these cases, the most pertinent question becomes how can international actors such as transnational human rights groups support those who chose to take this path, without further undermining their legitimacy and putting them at greater risk? One starting point might be the development of counter-narratives that tackle anti-civil 
society discourses and help to generate normative and cognitive legitimacy through changing perceptions about what civil society should be and do. This too will be a longterm process. As restrictions on civil society increase in different countries around the world, establishing which strategies for supporting at-risk organisations work and why represents an important area for future research.

Open Access This article is distributed under the terms of the Creative Commons Attribution 4.0 International License (http://creative commons.org/licenses/by/4.0/), which permits unrestricted use, distribution, and reproduction in any medium, provided you give appropriate credit to the original author(s) and the source, provide a link to the Creative Commons license, and indicate if changes were made.

Funding This work was supported by the Economic and Social Research Council (ESRC) Doctoral Training Centre, University of Oxford, UK (Grant Number ES/J500112/1).

\section{References}

ACT Alliance and CIDSE. (2014). Space for civil society: How to protect and expand an enabling environment. Geneva and Brussels: ACT Alliance and CIDSE.

Alliance, A. C. T. (2011). Shrinking political space of civil society action. Geneva: ACT Alliance.

Amnesty International. (2014). Burundi locked down: A shrinking of political space. London: Amnesty International.

Atack, I. (1998). Four criteria of development NGO legitimacy. World Development, 27(5), 855-864.

Beswick, D. (2010). Managing dissent in a post-genocide environment: The challenge of political space in Rwanda. Development and Change, 41(2), 225-251.

Brown, L. D. (2001). Civil society legitimacy: A discussion guide. In L. D. Brown (Ed.), Practice-research engagement and civil society in a globalizing world (pp. 63-80). Washington, DC and Cambridge, MA: Civicus and The Hauser Center.

Brown, L. D. (2008). Creating credibility: Legitimacy and accountability for transnational civil society. Sterling, VA: Kumarian Press.

Brown, L. D., \& Jagadananda, L. (2007). Civil society legitimacy and accountability: Issues and challenges. Cambridge: Civicus and The Hauser Center for Nonprofit Organizations, Civicus and The Hauser Center for Nonprofit Organizations.

Byrne, S., \& Klem, B. (2015). Constructing legitimacy in post-war transition: The return of 'normal' politics in Nepal and Sri Lanka. Geoforum, 66, 224-233.

Carothers, T., \& Brechenmacher, S. (2014). Closing space: Democracy and human rights support under fire. Washington, DC: Carnegie Endowment for International Peace.

Chahim, D., \& Prakash, A. (2014). NGOization, foreign funding, and the Nicaraguan Civil Society. VOLUNTAS: International Journal of Voluntary and Nonprofit Organizations, 25, 487-513.

Christensen, D., \& Weinstein, J. (2013). Defunding dissent: Restrictions on aid to NGOs. Journal of Democracy, 24(2), 77-91.

Civicus. (2013). State of civil society 2013: Creating an enabling environment. Johannesburg: Civicus.

Daley, P. (2008). Gender and genocide in Burundi: A search for spaces of peace in the Great Lakes region. Oxford: James Curry.

Dupuy, K. E., Ron, J., \& Prakash, A. (2015). Who survived? Ethiopia's regulatory crackdown on foreign-funded NGOs. Review of International Political Economy, 22(2), 419-456.
Edwards, M. (1999). Legitimacy and values in NGOs and international organizations: Some sceptical thoughts. In D. Lewis (Ed.), International perspectives on voluntary action: Reshaping the third sector (pp. 258-267). London: Earthscan.

Hayman, R., Crack, A., Okitoi, J., \& Lewis, S. (2014). Legal frameworks and political space for non-governmental organisations: An overview of six countries: Phase II. Brussels and Oxford: EADI and INTRAC.

Hayman, R., Lawo, T., Crack, A., Kontinen, T., Okitoi, J., \& Pratt, B. (2013). Legal frameworks and political space: An overview of six countries. Brussels and Oxford: EADI and INTRAC.

Human Rights Watch. (2010). Closing doors? The narrowing of democratic space in Burundi. New York: Human Rights Watch.

Human Rights Watch. (2012). "You will not have peace while you are living": The escalation of political violence in Burundi. New York: Human Rights Watch.

Jeffrey, A., McConnell, F., \& Wilson, A. (2015). Understanding legitimacy: Perspectives from anomalous geopolitical spaces. Geoforum, 66, 177-183.

Keck, M. E., \& Sikkink, K. (1998). Activists beyond borders. Ithaca: Cornell University Press.

Lemarchand, R. (1996). Burundi: Ethnic conflict and genocide. Cambridge: Woodrow Wilson Center Press and Cambridge University Press.

Lemarchand, R. (2009). The dynamics of violence in Central Africa. Philadelphia: University of Pennsylvania Press.

Lister, S. (2003). NGO legitimacy: Technical issue or social construct? Critique of Anthropology, 23(2), 175-192.

Suchman, M. C. (1995). Managing legitimacy: Strategic and institutional approaches. Academy of Management Review, 20(3), 571-610.

Trócaire. (2012). Democracy in action: Protecting civil society space. Maynooth: Trócaire.

United Nations Human Rights Council. (2014). Concept note. Panel discussion on the importance of the promotion and protection of civil society space, 25th Session of the Human Rights Council. Geneva: United Nations Human Rights Council.

Uvin, P. (1999). Ethnicity and power in Burundi and Rwanda: Different paths to mass violence. Comparative Politics, 31(3), 253-271.

Uvin, P. (2009). Life after violence: A people's story of Burundi. London: Zed Books.

van der Borgh, C., \& Terwindt, C. (2014). NGOs under pressure in partial democracies. London: Palgrave Macmillan.

Walton, O. (2008). Conflict, peacebuilding and NGO legitimacy: National NGOs in Sri Lanka. Conflict, Security and Development, 8(1), 133-167.

Walton, O. (2013). 'Everything is Politics': Understanding the political dimensions of NGOs legitimacy in conflict-affected regions. In R. Brown \& J. Pierce (Eds.), Charities in the nonWestern world (pp. 19-39). Abingdon: Routeledge.

Walton, O., Davies, T., Thrandardottir, E., \& Keating, V. C. (2016). Understanding contemporary legitimacy challenges to INGO legitimacy: Integrating top-down and bottom-up perspectives. VOLUNTAS: International Journal of Voluntary and Nonprofit Organizations, 27, 2764-2786.

Watt, N. (2008). Burundi: The biography of a small African country. London: Hurst \& Company.

Weber, M. (1964). The theory of social and economic organization. (T. Parsons, Ed.) New York: Free Press.

Wood, J. (2016). Unintended consequences: DAC governments and shrinking civil society space in Kenya. Development in Practice, 26(5), 532-543.

World Movement for Democracy and INCL. (2012). Defending civil society. Washington, DC: World Movement for Democracy and INCL. 